\title{
PENGARUH KEAMANAN, REPUTASI DAN PENGALAMAN TERHADAP TRUST PENGGUNA INTERNET UNTUK BERTRANSAKSI SECARA ONLINE
}

\author{
Nur Afiah \\ Akuntansi Universitas Negeri Makassar \\ Email: nurafiah@unm.ac.id
}

\begin{abstract}
The aims of the research are to analyze to what extent the influence of security, reputation and experience on the trust of internet users for online interaction. The samples of the research were e-commerce users in Indonesia by taking the customers of one of the vendors of online shops, i.e. Lazada.co.id. The main instrument to collect the data was questionnaire measured by likert scale. The respondents consisted of 100 people. All questionnaires were given directly to respondents. Only 73 questionnaires were processed since 19 of them were not returned and 8 were not completed. The data were analyzed by using multiple regression analysis. The result reveal that independent variablest consisting of security, reputation, and experience have influence on customers' trust. Security and reputation are the only variables which have a positive and significant influence on customers' trust, while experience variable has a positive but insignificant influence. Thus, good security and reputation are very important variables in influencing the trust of e-commerce customers in Indonesia.
\end{abstract}

Keywords: e-commerce, security, reputation, experience and trust.

\begin{abstract}
Abstrak. Tujuan dari penelitian ini adalah untuk menganalisis sejauh mana pengaruh keamanan, reputasi dan pengalaman terhadap kepercayaan pengguna internet untuk bertransaksi secara online. Sampel penelitian adalah pengguna e-commerce di Indonesia dengan mengambil pelanggan dari salah satu vendor toko online yaitu Lazada.co.id. Instrumen utama dalam mengumpulkan data adalah kuesioner yang diukur dengan skala Likert. Responden terdiri dari 100 orang. Semua kuesioner diberikan langsung kepada responden. Hanya 73 kuesioner yang diproses karena 19 tidak dikembalikan dan 8 tidak terisi secara lengkap. Data dianalisis dengan analisis regresi berganda. Hasilnya mengungkapkan bahwa variabel independen yang terdiri dari keamanan, reputasi dan pengalaman memiliki pengaruh terhadap kepercayaan pengguna internet. Hanya variabel keamanan dan reputasi yang memiliki pengaruh positif dan signifikan terhadap kepercayaan pengguna internet, sedangkan variabel pengalaman memiliki pengaruh positif tetapi tidak signifikan. Dengan demikian, keamanan dan reputasi yang baik merupakan variabel yang sangat penting dalam mempengaruhi kepercayaan pengguna ecommerce di Indonesia.
\end{abstract}

Kata Kunci: e-commerce, keamanan, reputasi, pengalaman dan kepercayaan.

\section{PENDAHULUAN}

Perkembangan teknologi elektronik yang berlangsung sangat pesat telah mempengaruhi hampir seluruh aspek kehidupan dan kegiatan masyarakat. Canggihnya teknologi modern saat ini dan terbukanya jaringan informasi global yang serba transparan, telah ditandai dengan munculnya internet. Dengan teknologi internet, human action (perilaku manusia), human interaction (interaksi antar manusia), human relation (hubungan kemanusiaan) mengalami perubahan yang cukup signifikan. Jaringan komunikasi global telah menciptakan tantangan-tantangan terhadap cara pengaturan transaksi-transaksi sosial dan ekonomi.

Internet telah memberikan kemudahan dalam berkomunikasi secara global tanpa batasan geografis antar negara. Internet 
merupakan suatu penemuan yang pada awalnya berfungsi sebagai alat pertukaran data ilmiah dan akademik, kini telah berubah menjadi perlengkapan hidup sehari-hari dan dapat diakses dari berbagai belahan dunia. Teknologi internet mempunyai pengaruh yang sangat besar terhadap perekonomian dunia. Internet membawa perekonomian dunia memasuki babak baru yang lebih populer dengan istilah digital economics atau ekonomi digital.

Pengguna internet di Indonesia sudah mencapai 143.260.000 per Desember 2017 dari total populasi penduduk 266 juta jiwa, dan sekarang tentunya akan meningkat dari angka tersebut (internetwordstats.com). Indonesia sendiri boleh berbangga dengan berada pada peringkat ke 5 pengguna internet terbesar di dunia dengan tingkat pertumbuhan 7,063\% sampai dengan tahun 2017. Kondisi tersebut dapat dijadikan pemicu untuk menumbuhkan $e$ commerce di Indonesia. Dengan semakin banyaknya pengguna internet, diharapkan dapat mempengaruhi perilaku masyarakat dalam melakukan pembelian barang/jasa, yaitu dari pembelian secara konvensional ke e-commerce.

Pertumbuhan e-commerce di seluruh dunia yang semakin pesat membawa dampak tersendiri bagi Indonesia. Pemanfaatan teknologi informasi disamping memberi manfaat bagi masyarakat, juga memiliki peluang disalahgunakan untuk melakukan kejahatan. Disamping pertumbuhan pengguna internet juga terdapat trend meningkatnya kejahatan internet di Indonesia.

Kejahatan melalui internet (cyberfraud/internetfraud) dalam berbagai bentuknya, baik di Indonesia maupun di belahan dunia lainnya masih menjadi ancaman bagi keberlangsungan e-commerce. Berdasarkan laporan State of the Inernet pada tahun 2013, Indonesia dinyatakan berada di urutan ke dua negara asal pelaku cyberfraud. Sejak 2012 sampai dengan April 2015, Subdit IT/ Cyber Crime telah menangkap 497 orang tersangka kasus kejahatan di dunia maya. Dari jumlah tersebut, sebanyak 389 orang di antaranya merupakan warga negara asing, dan 108 orang merupakan warga negara Indonesia.

Bangunan sistem e-commerce sebaik apapun pasti masih mengandung potensi risiko. Sebagaimana penelitian yang dilakukan oleh Pavlou dan Gefen (2002), Corbit et al. (2003), Kim dan Tadisina (2003), Mukherjee dan Nath (2003), dan peneliti yang lain dari sekian banyak faktor yang dapat mempengaruhi terjadinya transaksi melalui $e$ commerce, faktor kepercayaan (trust) menjadi faktor kunci. Hanya pelanggan yang memiliki kepercayaan yang akan berani melakukan transaksi melalui media internet. Tanpa ada kepercayaan dari pelanggan, mustahil transaksi e-commerce akan terjadi.

Indonesia sebagai negara sedang berkembang, tentunya memiliki beberapa perbedaan dengan negara-negara maju yang telah lama mempraktikkan e-commerce. Perbedaan tersebut setidaknya menyangkut masalah regulasi, perangkat hukum, dan perilaku konsumen. Berkaitan dengan praktik e-commerce di Indonesia, fenomena yang menarik untuk diteliti adalah sejauhmana kepercayaan (trust) pelanggan e-commerce dalam melakukan transaksi online.

Berdasarkan latar belakang tersebut di atas, maka masalah dalam penelitian ini dirumuskan sebagai berikut: (1) apakah ada pengaruh keamanan terhadap kepercayaan (trust) pengguna internet untuk bertransaksi secara online?; (2) apakah ada pengaruh reputasi terhadap kepercayaan (trust) pengguna internet untuk bertransaksi secara online? (3) apakah ada pengaruh pengalaman terhadap kepercayaan (trust) pengguna internet untuk bertransaksi secara online?

Mengacu pada rumusan masalah di atas, maka tujuan penelitian ini adalah: menganalisis berapa besar pengaruh keamanan, reputasi dan pengalaman terhadap kepercayaan (trust) pengguna internet untuk bertransaksi secara online.

\section{E-commerce}

E-commerce pada dasarnya adalah kegiatan transaksi perdagangan melalui media elektronik. Dampaknya yang signifikan adalah tersingkirnya jejak kertas yang sebelumnya merupakan bagian tak terpisahkan dari transaksi tradisional. Kalakota dan Whinston (Suyanto 2003;11), mendefinisikan e-commerce dari beberapa perspektif, yaitu: (1) dari perspektif komunikasi, e-commerce adalah pengiriman informasi, produk/jasa, atau pembayaran melalui jaringan telepon, atau jalur komunikasi lainnya; (2) dari perspektif proses bisnis, e-commerce adalah aplikasi teknologi menuju otomatisasi transaksi bisnis dan work flow; (3) dari perspektif pelayanan, e-commerce adalah alat yang digunakan untuk mengurangi biaya dalam pemesanan dan pengiriman barang.

Gao (2008), menyatakan e-commerce adalah penggunaan jaringan komputer untuk 
melakukan komunikasi bisnis dan transksaksi komersial. Kemudian dalam website $e$ commerce.net, e-commerce didefinisikan sebagai kegiatan menjual barang dagangan dan/atau jasa melalui internet. Seluruh komponen yang terlibat dalam bisnis tersebut praktis diaplikasikan disini, seperti pelayanan konsumen, produk yang tersedia, cara pembayaran, jaminan atas produk yang dijual, cara promosi dan sebagainya. Seluruh definisi yang dijelaskan di atas pada dasarnya memiliki kesamaan yang mencakup komponen transaksi (pembeli, penjual, barang, jasa dan informasi), subyek dan obyek yang terlibat, serta media yang digunakan yaitu internet.

\section{Trust dalam e-commerce}

Trust merupakan pondasi dari bisnis. Suatu transaksi bisnis antara dua pihak atau lebih akan terjadi apabila masing-masing saling mempercayai. Kepercayaan (trust) ini tidak begitu saja dapat diakui oleh pihak lain/mitra bisnis, melainkan harus dibangun mulai dari awal dan dapat dibuktikan.

Ridings et al. (2002) meneliti mengenai penyebab dan pengaruh kepercayaan (trust) pada komunitas maya. Hasil dari penelitian ini menjelaskan bahwa kepercayaan (trust) merupakan prediktor yang signifikan pada keinginan anggota komunitas maya untuk saling berbagi dan saling memperoleh informasi. Perhatian, keterbukaan, dan watak yang baik dapat membangun kepercayaan. Kepercayaan merupakan aspek terpenting dalam komunitas maya. Kepercayaan di antara para anggota komunitas maya akan semakin besar apabila mereka saling mengetahui secara personal.

Gefen (2002) melakukan penelitian mengenai kaitan antara trust dengan loyalitas pelanggan e-commerce. Hasil dari penelitian ini menunjukkan bahwa loyalitas konsumen tergantung pada kemampuan vendor dalam mengelola kepercayaan konsumen melalui kualitas pelayanan. Kualitas pelayanan melalui peningkatan kepercayaan mempunyai kontribusi yang besar di dalam membentuk loyalitas konsumen.

Mukherjee dan Nath (2003) meneliti mengenai model kepercayaan (trust) pada online banking. Hasil yang diperoleh dari penelitian ini menunjukkan bahwa shared value dan communication memiliki pengaruh positif yang signifikan terhadap trust. Sedangkan opportunistic behavior memiliki pengaruh negatif terhadap trust. Shared value, di samping memiliki pengaruh signifikan terhadap trust, juga memiliki pengaruh signifikan baik secara langsung maupun tidak langsung terhadap commitment. Selain itu, commitment juga dipengaruhi secara signifikan oleh trust.

\section{Keamanan dan Trust}

Pelanggan e-commerce masih takut ada pencuri kartu kredit, rahasia informasi personal mereka menjadi terbuka, dan kinerja jaringan yang kurang baik. Umumnya pembeli masih belum yakin bahwa akan menguntungkan dengan menyambung ke internet, mencari situs shopping, menunggu download gambar, mencoba mengerti bagaimana cara memesan sesuatu, dan kemudian harus takut apakah nomor kartu kredit mereka di ambil oleh hacker.

$$
\text { Miyazaki dan Fernandez (2001) }
$$
menemukan keamanan sistem dihubungkan dengan tingkat tarif dari produk online yang dibeli oleh konsumen. Bagaimanapun, tidak ada hubungan negatif antara kehadiran statemen keamanan dan privasi dan resiko yang ditemukan. Dalam studi yang sama, keamanan dan privasi secara positif dihubungkan dengan kemungkinan pembelian secara online.

Konsumen yang merasa aman terhadap lingkungan internet secara keseluruhan akan cenderung percaya terhadap website yang menyediakan pelayanan e-commerce dibandingkan dengan orang yang merasa bahwa internet tidak aman karena tidak yakin adanya perlindungan yang memadai di situs $e$ commerce (Gefen et al., 2003). Sehingga persepsi yang baik terhadap structural assurance akan menimbulkan trust terhadap situs e-commerce.

H1: Keamanan berpengaruh secara positif dan signifikan terhadap kepercayaan (trust) pengguna internet untuk bertransaksi secara online.

\section{Reputasi dan Trust}

Penjual berusaha menghindarkan hal yang menyebabkan mereka memperoleh reputasi buruk. Perceived reputation memberikan keyakinan kepada pihak lain mengenai kemampuan, integritas dan goodwill. Biasanya dalam situs-situs online akan mencantumkan testimoni-testimoni dari pelanggannya untuk membuktikan bahwa reputasi perusahaan atau toko online yang bersangkutan baik berdasarkan pengalaman yang mereka lakukan selama bertransaksi di situs tersebut. Kesaksian konsumen tentang pengalaman bertransaksi di toko online merupakan salah satu hal yang 
dilakukan situs e-commerce untuk mempersepsikan dirinya memiliki reputasi baik.

Dharma (2006) meneliti tentang pengaruh perceived reputation terhadap trust pengguna internet untuk bertransaksi $e$ commerce. Kesimpulan yang dihasilkan yaitu bahwa kepercayaan (trust) pengguna internet di Indonesia terhadap sistem e-commerce juga dipengaruhi oleh variabel perceived reputation secara signifikan.

H2: Reputasi berpengaruh secara positif dan signifikan terhadap kepercayaan (trust) pengguna internet untuk bertransaksi secara online.

\section{Pengalaman dan Trust}

Venkatesh dan Davis (2007), pengembangan TAM yang memfokuskan pada variabel awal dari kemudahan penggunaan, secara teoritis menyatakan bahwa pengalaman langsung dengan perangkat lunak menjadi perantara dalam hubungan langsung antara tujuan penggunaan dan kemudahan penggunaan. Venkatesh (2000) menemukan bahwa pengalaman tidak memerankan peranan sebanyak peranannya seperti yang diharapkan dalam menjelaskan varian dalam kemudahan penggunaan disadari. Kepercayaan pada general sistem independent tentang komputer lebih menjadi peramal yang lebih kuat dari kemudahan penggunaan disadari dari pada pengalaman, selama tiga periode.

Walczuch et al. (2001) melakukan studi mengenai faktor-faktor psikologis yang mempengaruhi kepercayaan konsumen dalam $e$ retailing (belanja secara elektronik). Pengalaman yang cukup banyak dalam mempergunakan internet, akan menumbuhkan trust pada konsumen. Trust ini selanjutnya akan mempunyai dampak yang besar bagi konsumen untuk ikut berpartisipasi melakukan pembelian secara online.

H3: Pengalaman menggunakan internet berpengaruh secara positif dan signifikan terhadap kepercayaan (trust) pengguna internet untuk bertransaksi secara online.

\section{Model Penelitian}

Dari hipotesis yang dirumuskan di atas, maka model penelitiannya dapat digambarkan sebagai berikut.
Gambar 1: Model Penelitian

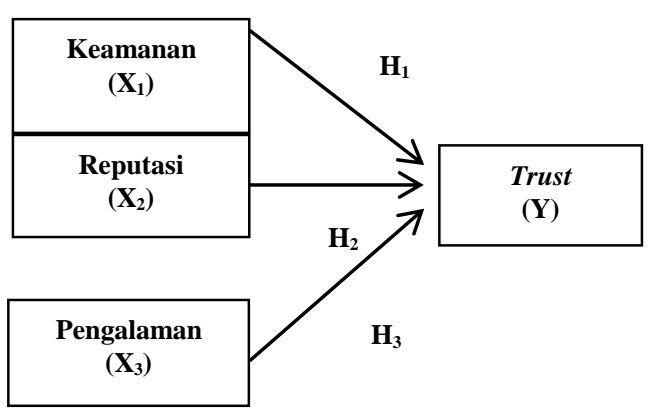

\section{METODE PENELITIAN}

Populasi dalam penelitian ini adalah pengguna internet di Indonesia yang melakukan transaksi pembelian barang/jasa melalui $e$ commerce. Sampel penelitian mengambil pengguna e-commerce di Indonesia dengan sasaran pelanggan salah satu vendor toko online terbesar di Indonesia, yaitu Lazada.co.id.

Instrumen utama pengumpulan data berupa kuesioner dan diukur dengan skala likert. Penelitian ini menggunakan 100 responden. Kuesioner diberikan secara langsung kepada responden. Data yang terolah sebanyak 73 karena sebanyak 19 kuesioner tidak kembali dan 8 tidak diisi secara lengkap.

Variabel dalam penelitian ini adalah variabel independen yaitu keamanan $\left(\mathrm{X}_{1}\right)$, reputasi $\left(\mathrm{X}_{2}\right)$, dan pengalaman $\left(\mathrm{X}_{3}\right)$ dan variabel dependen yaitu trust $(\mathrm{Y})$.

Keamanan $\left(\mathrm{X}_{1}\right)$ mengacu pada tingkat kepercayaan terhadap informasi pribadi yang dipancarkan internet dijamin dan tidak akan diakses oleh orang lain. Variabel keamanan diukur dengan menggunakan 4 item pertanyaan yang diadaptasi dari Yaobin dan Tao (2007).

Reputasi $\quad\left(\mathrm{X}_{2}\right)$ adalah keyakinan konsumen bahwa organisasi yang menjual barang atau jasa akan jujur dan peduli kepada konsumen mereka. Variabel reputasi diukur menggunakan instrumen yang dipakai Kim, et al. (2008) terdiri dari 5 item pertanyaan.

Pengalaman

merujuk pada pengetahuan dan ketrampilan tentang sesuatu yang diperoleh lewat keterlibatan atau berkaitan dengannya selama periode tertentu. Variabel pengalaman diukur dengan menggunakan 4 item pertanyaan yang diadaptasi dari Corbitt et al. (2003).

Kepercayaan adalah kesediaan seseorang untuk menggantungkan dirinya pada pihak lain dengan resiko tertentu. Variabel kepercayaan diukur dengan menggunakan 6 
item pertanyaan berdasarkan 3 item indikator yang diadaptasi dari Corbitt et al. (2003).

\section{Teknik Analisis Data}

Teknik anaisis data terdiri dari empat jenis analisis yaitu, uji kualitas data yang terdiri dari uji validitas dan reliabilitas. Kedua adalah uji asumsi klasik yang terdiri dari uji normalitas, multikolinearitas, dan heteroskedastisitas. Ketiga adalah analisis regresi linear berganda, dan terakhir adalah uji hipotesis yang terdiri dari uji parsial (uji t) dan uji simultan (uji f). Analisis yang digunakan dalam penelitian ini adalah analisis kuantitatif.

\section{HASIL DAN PEMBAHASAN}

Responden wanita berjumlah lebih banyak dari pria yaitu wanita sebanyak 64 orang, dan pria sebanyak 9 orang. Untuk umur responden diperoleh $<20$ tahun berjumlah 6 orang, 20 - 30 tahun berjumlah 25 orang, $30-$ 40 tahun berjumlah 38 orang, dan sisanya $>40$ tahun hanya sebanyak 4 orang. Data tentang pengalaman menggunakan internet, responden dengan pengalaman $1-5$ tahun sebanyak 24 orang dan 5-10 tahun sebanyak 21 orang. Untuk tingkat pengalaman < 1 tahun berjumlah 26 orang. Untuk tingkat sangat pengalaman apabila sudah lebih dari 10 tahun menggunakannya, responden yang diperoleh hanya 2 orang saja. Untuk data tempat mengakses internet, diperoleh responden mengakses melalui kantor 20 orang. Kemudian melalui rumah sebanyak 19 orang. Ada 14 responden yang mengakses lewat handphone, dan melalui cafe/warkop sebanyak 9 orang, warnet 7 orang dan sisanya sebanyak 4 orang mengakses melalui fasilitas wi-fi kampus.

\section{Hasil Uji Validitas}

Semua item pertanyaan mengenai variabel keamanan $\left(\mathrm{X}_{1}\right)$, reputasi $\left(\mathrm{X}_{2}\right)$, pengalaman $\left(\mathrm{X}_{3}\right)$ dan trust $(\mathrm{Y})$ yang terdapat dalam daftar pertanyaan (kuesioner) dianggap valid karena $r$ menunjukan positif dan $r$-hitung $>$ r-tabel, sehingga pengujian dapat dilanjutkan pada pengujian reliabilitas (lihat tabel 4.1).

Tabel 4.1 Hasil Uji Validitas Variabel Keamanan $\left(\mathrm{X}_{1}\right)$, Reputasi $\left(\mathrm{X}_{2}\right)$, Pengalaman $\left(\mathrm{X}_{3}\right)$ dan Trust $(\mathrm{Y})$

\begin{tabular}{ccccc}
\hline Trust $(\mathbf{Y})$ & Keamanan (X1) & Reputasi (X2) & $\begin{array}{c}\text { Pengalaman } \\
(\mathbf{X 3})\end{array}$ & Ket \\
\hline 0,637 & 0,555 & 0,597 & 0,527 & Valid \\
0,582 & 0,771 & 0,683 & 0,566 & Valid \\
0,709 & 0,416 & 0,635 & 0,669 & Valid \\
0,724 & 0,724 & 0,531 & 0,519 & Valid \\
0,547 & & 0,562 & & Valid \\
0,559 & & & & Valid \\
\hline
\end{tabular}

r_tabel $=0,230$

Sumber: Data diolah, 2018

\section{Hasil Uji Reliabilitas}

Semua item pertanyaan mengenai variabel keamanan $\left(\mathrm{X}_{1}\right)$, reputasi $\left(\mathrm{X}_{2}\right)$, pengalaman $\left(\mathrm{X}_{3}\right)$ dan trust $(\mathrm{Y})$ yang terdapat dalam daftar pertanyaan (kuesioner) dianggap reliabel karena nilai Croanbach's Alpha menunjukan nilai > 0,60. Menurut klasifikasi Sekaran (2006) dapat disimpulkan bahwa semua item pertanyaan dikatakan reliabel dengan kategori reliabilitas diterima (lihat tabel 4.2).

Tabel 4.2 Hasil uji reliabilitas variabel keamanan $\left(\mathrm{X}_{1}\right)$, reputasi $\left(\mathrm{X}_{2}\right)$, pengalaman $\left(\mathrm{X}_{3}\right)$ dan trust $(\mathrm{Y})$

\begin{tabular}{lcc}
\hline \multicolumn{1}{c}{ Variabel } & Cronbach's Alpha & Nof items \\
\hline Keamanan $\left(\mathrm{X}_{1}\right)$ & .797 & 4 \\
Reputasi $\left(\mathrm{X}_{2}\right)$ & .811 & 5 \\
Pengalaman $\left(\mathrm{X}_{3}\right)$ & .768 & 4 \\
Trust $(\mathrm{Y})$ & .843 & 6 \\
\hline
\end{tabular}

Sumber: Data diolah, 2018

\section{Hasil Uji Asumsi Klasik}

Mendeteksi adanya multikolinearitas dapat diketahui dengan melihat nilai Variance Inflation Faktor (VIF) dan Nilai Tolerence
Valuenya (TOL). Suatu model dinamakan bebas dari gejala multikolinearitas jika nilai VIFnya dibawah 10 dan nilai TOLnya di atas 0,01 (lihat 
tabel 4.3). $X_{1}, X_{2}$ dan $X_{3}$ mempunyai nilai Variance Inflation Faktor (VIF) dibawah dari 10 dan Nilai Tolerence Valuenya (TOL) diatas
0,01 . Hal ini berarti bahwa model di atas bebas dari gejala multikolinearitas.

Tabel 4.3 Hasil uji multikolinearitas

\begin{tabular}{lcc}
\hline \multirow{2}{*}{ Model } & \multicolumn{2}{c}{ Collinearity Statistics } \\
\cline { 2 - 3 } & Model & VIF \\
\hline Keamanan $\left(\mathrm{X}_{1}\right)$ & .300 & 3.333 \\
Reputasi $\left(\mathrm{X}_{2}\right)$ & .352 & 2.842 \\
Pengalaman $\left(\mathrm{X}_{3}\right)$ & .272 & 3.676 \\
\hline
\end{tabular}

Dependent variable: Trust (Y)

Sumber: Data diolah, 2018

\section{Pengujian Hipotesis}

Hasil pengujian regresi pada table 4.4 menunjukkan bahwa pada taraf signifikansi alpha $(\alpha)=0,05$; variabel keamanan $\left(\mathrm{X}_{1}\right)$ dengan nilai signifikan $0,00<$ alpha $(\alpha)$, maka dapat disimpulkan bahwa keamanan berpengaruh signifikan terhadap trust. Kemudian reputasi
$\left(\mathrm{X}_{2}\right)$ dengan nilai signifikan $0,010<$ alpha $(\alpha)$, maka dapat disimpulkan bahwa reputasi memiliki pengaruh signifikan terhadap trust, sedangkan pengalaman $\left(\mathrm{X}_{3}\right)$ dengan nilai 0,487 $>$ alpha $(\alpha)$, maka dapat disimpulkan bahwa pengalaman tidak memiliki pengaruh signifikan terhadap trust.

Tabel 4.4 Hasil pengujian regresi

\begin{tabular}{lccccc}
\hline \multirow{2}{*}{ Model } & \multicolumn{2}{c}{ Unstand. Koef. } & Stand. Koef. & T & \multirow{2}{*}{ Sig } \\
\cline { 2 - 4 } & B & SE & Beta & & \\
\hline (Constant) & .889 & .837 & & 1.063 & 292 \\
Keamanan $\left(\mathrm{X}_{1}\right)$ & .937 & .148 & .630 & 6.326 & .000 \\
Reputasi $\left(\mathrm{X}_{2}\right)$ & .293 & .111 & 243 & 2.647 & .010 \\
Pengalaman $\left(\mathrm{X}_{3}\right)$ & .103 & .147 & .073 & .699 & .487 \\
\hline
\end{tabular}

Dependent Variable: Trust_Y

Sumber: Data diolah, 2018

Hasil pengujian signifikansi simultan pada table 4.5 menunjukkan nilai $\mathrm{F}$ hitung sebesar 89.085 dengan tingkat signifikansi 0,0000. Dari hasil tersebut disimpulkan bahwa

variabel keamanan $\left(\mathrm{X}_{1}\right)$, reputasi $\left(\mathrm{X}_{2}\right)$, dan pengalaman $\left(\mathrm{X}_{3}\right)$ secara simultan berpengaruh terhadap trust, maka model regresi dapat digunakan untuk memprediksi variabel trust. $(0,000)$ jauh lebih kecil dari 0,05 . Oleh karena

Tabel 4.5 Pengujian signifikansi simultan

\begin{tabular}{lrcccc}
\hline \multicolumn{1}{c}{ Model } & Sum of squares & df & Mean Square & F & Sig. \\
\hline Regression & 982.392 & 3 & 327.464 & 89.085 & $.000^{\mathrm{a}}$ \\
Residual & 253.635 & 69 & 3.676 & & \\
Total & 1236.027 & 72 & & & \\
\hline
\end{tabular}

a. Predictors: (Constant), Pengalaman_X3, Reputasi_X2, Keamanan_X1

b. Dependent variable: Trust_Y

Sumber: Data diolah, 2018

Hasil pengujian tabel 4.6 menunjukkan nilai Adjusted $R$ Square sebesar 0,786 yang berarti bahwa variasi variabel trust dapat dijelaskan oleh ketiga variabel independen yaitu keamanan $\left(\mathrm{X}_{1}\right)$, reputasi $\left(\mathrm{X}_{2}\right)$ dan pengalaman $\left(\mathrm{X}_{3}\right)$ sebesar $78,6 \%$ sedang sisanya dijelaskan oleh faktor lain yang berasal dari luar model. Nilai Adjusted R square yang diperoleh dapat

disimpulkan bahwa variabel keamanan $\left(\mathrm{X}_{1}\right)$, reputasi $\left(\mathrm{X}_{2}\right)$ dan pengalaman $\left(\mathrm{X}_{3}\right)$ secara bersama-sama berpengaruh pada munculnya trust pengguna internet untuk bertransaksi secara online adalah sebesar 78,6\%. Dengan demikian dapat disimpulkan bahwa model regresi cukup kuat dijadikan sebagai model prediksi yang baik karena menghasilkan kontribusi yang cukup 
besar untuk dapat digunakan memprediksi faktor

yang mempengaruhi trust.

Tabel 4.6 Kontribusi model terhadap variabel $\mathrm{Y}$

\begin{tabular}{lcccc}
\hline Model & $\mathbf{R}$ & R square & Adjusted R Square & $\begin{array}{c}\text { Std. Error of the } \\
\text { Estimate }\end{array}$ \\
\hline 1 & $.892^{\mathrm{a}}$ & .795 & .786 & 1.91726 \\
\hline
\end{tabular}

a. Predictors: (Constant), Pengalaman_X3, Reputasi_X2, Keamanan_X1

b. Dependent Variable: Trust_Y

Sumber: Data diolah, 2018

\section{PEMBAHASAN}

\section{Pengujian Hipotesis 1}

Hipotesis pertama $\left(\mathrm{H}_{1}\right)$ dalam penelitian ini menyatakan bahwa keamanan berpengaruh secara positif dan signifikan terhadap kepercayaan (trust) pengguna internet untuk bertransaksi secara online. Dalam tabel 4.4 diketahui bahwa nilai t hitung untuk $\mathrm{X}_{1}$ sebesar 6.326 dengan nilai signifikansi 0.00 lebih kecil dari taraf signifikansi alpha $(\alpha)$, sehingga disimpulkan bahwa keamanan berpengaruh secara positif dan signifikan terhadap trust pengguna internet untuk bertransaksi secara online. Dengan demikian, hipotesis pertama $\left(\mathrm{H}_{1}\right)$ diterima.

\section{Pengujian Hipotesis 2}

Hipotesis kedua $\left(\mathrm{H}_{2}\right)$ dalam penelitian ini menyatakan reputasi berpengaruh secara positif dan signifikan terhadap kepercayaan (trust) pengguna internet untuk bertransaksi secara online. Dalam tabel 4.4 diketahui bahwa nilai t hitung untuk $\mathrm{X}_{2}$ sebesar 2.647 dengan nilai signifikansi 0.010 lebih kecil dari taraf signifikansi alpha $(\alpha)$. Dari hasil tersebut dapat disimpulkan bahwa reputasi memiliki pengaruh positif dan signifikan terhadap trust pengguna internet untuk bertransaksi secara online. Dengan demikian, hipotesis kedua $\left(\mathrm{H}_{2}\right)$ diterima.

\section{Pengujian Hipotesis 3}

Hipotesis ketiga $\left(\mathrm{H}_{3}\right)$ menyatakan bahwa pengalaman menggunakan internet berpengaruh secara positif dan signifikan terhadap kepercayaan (trust) pengguna internet untuk bertransaksi secara online. Dalam tabel 4.4 diketahui bahwa nilai $\mathrm{t}$ hitung untuk $\mathrm{X}_{3}$ sebesar 0.699 dengan nilai signifikansi 0.487 lebih besar dari taraf signifikansi alpha $(\alpha)$. Dari hasil tersebut dapat disimpulkan bahwa pengalaman memiliki pengaruh positif tetapi tidak signifikan (lemah) terhadap trust pengguna internet untuk bertransaksi secara online. Dengan demikian, hipotesis ketiga $\left(\mathrm{H}_{3}\right)$ ditolak.

\section{SIMPULAN DAN SARAN Simpulan}

Berdasarkan analisis data diperoleh bahwa terdapat pengaruh positif dan signifikan antara keamanan dan reputasi terhadap trust pengguna internet untuk bertransaksi secara online. Hal ini menandakan bahwa keyakinan terhadap adanya mekanisme kontrol dan prosedur keamanan seperti sertifikasi pengamanan dari pihak ketiga serta enkripsi untuk menjamin kerahasiaan informasi yang memadai terhadap situs e-commerce akan menimbulkan trust pengguna internet. $E$ commerce harus mampu menawarkan keamanan yang setara dengan keamanan dalam dunia nyata. Kesaksian konsumen tentang pengalaman bertransaksi di toko online merupakan salah satu hal yang dilakukan situs e-commerce untuk mempersepsikan bahwa toko online tersebut memiliki reputasi yang baik.

Pengalaman memilki pengaruh yang positif tetapi tidak signifikan terhadap trust pengguna internet untuk bertransaksi secara online. Responden pada umumnya menganggap bahwa pengalaman menggunakan internet ternyata bukan jaminan untuk melakukan transaksi online.

\section{Saran}

Penelitian ini akan berguna jika hasil analisisnya dapat digunakan sebagai usulan perbaikan dalam kesediaan konsumen untuk membeli barang atau jasa secara online. Adapun implikasi penelitian ini adalah memberikan pemahaman adopsi sistem e-commerce pada level individu dan diharapkan dapat memberikan gambaran kepada pengguna internet bahwa dalam transaksi online, konsumen terlebih dahulu untuk melakukan pencarian informasi mengenai kredibilitas suatu toko online, sehingga pengguna merasa aman ketika melakukan transaksi secara online. 
Penelitian selanjutnya dapat menggunakan sampel yang lebih besar dari kalangan profesional, sehingga akan menghasilkan kondisi yang sebenarnya dan respresentatif. Selain itu, penelitian ini dapat dikembangkan model dengan menambahkan variabel lain yang belum digunakan dalam penelitian ini seperti serivice quality, product category, income, gender dan persepsi resiko.

\section{DAFTAR RUJUKAN}

Corbitt, B. J., Thanasankit, T., dan Yi, H., 2003. Trust and E-commerce: a Study of Consumer Perceptions, Electronic Commerce Research and Application, 2: 203-215.

Dharma, F., 2006, Pengaruh Structural Assurance dan Perceived Reputation Terhadap Trust Pengguna Internet di Sistem E-Commerce, SNA 9 Padang.

Gao, Y., 2008. Electronic Commerce: Concepts, Methodologies, Tools, and Applications; Encyclopedia of Information Science and Technology, Florida Institute of Technology, USA.

Gefen, D., 2002. Customer Loyalty in ECommerce, Journal of the Association for Information Systems, 3:27-51.

Kim, D. J., Ferrin, D. L., dan Rao, H. R., 2008. A Trust-Based Consumer Decision-Making Model in Electronic Commerce: The Role of Trust, Perceived Risk, and Their Antecedents, Decision Support Systems 44, pp. 544-564.
Miyazaki, A. D., and Fernandez, A. 2001. "Consumer Perceptions of Privacy and Security Risks for Online Shopping." Journal of Consumer Affairs, 35(1), 27-44.

Mukherjee, A., dan Nath, P., 2003. A Model of Trust in Online Relationship Banking, International Journal of Bank Marketing, 21 (1): 5-15.

Pavlou, P. A., dan Gefen, D., 2002. Building Effective Online Marketplaces with Institution-based Trust, Proceedings of Twenty-Third International Conference on Information Systems, pp. 667-675.

Ridings, C. M., Gefen, D., dan Arinze, B., 2002. Some Antecedents and Effect of Trust in Virtual Communities, Journal of Strategic Information Systems, 11: 271295.

Suyanto M, 2003, Strategi Periklanan pada eCommerce Perusahaan Top Dunia, Andi, Yogyakarta.

Venkatesh, V. and Davis, F.D. 2007. A model of the antecedents of perceived ease of use: development and test. Decision Sciences. Vol. 27 No. 3. h. 451-481

Walczuch, R., Seelen, J., dan Lundgren, H., 2001. Psychological Determinants for Consumer Trust in E-Retailing, Proceedings of Eighth Research Symposium on Emerging Electronic Market, pp. 1-21.

Yaobin, L., dan Tao, Z., 2007. A Research of Consumers' Initial Trust in Online Stores in China. Journal or Research and Practice in Information Technology, 39(3). 